\title{
Individualised isotoxic accelerated radiotherapy and chemotherapy are associated with improved long-term survival of patients with stage III NSCLC: A prospective population-based study
}

Citation for published version (APA):

De Ruysscher, D., van Baardwijk, A., Steevens, J., Botterweck, A., Bosmans, G., Reymen, B., Wanders, R., Borger, J., Dingemans, A-M. C., Bootsma, G., Pitz, C., Lunde, R., Geraedts, W., Oellers, M., Dekker, A., \& Lambin, P. (2012). Individualised isotoxic accelerated radiotherapy and chemotherapy are associated with improved long-term survival of patients with stage III NSCLC: A prospective populationbased study. Radiotherapy and Oncology, 102(2), 228-233. https://doi.org/10.1016/j.radonc.2011.10.010

Document status and date:

Published: 01/02/2012

DOI:

10.1016/j.radonc.2011.10.010

Document Version:

Publisher's PDF, also known as Version of record

Document license:

Taverne

Please check the document version of this publication:

- A submitted manuscript is the version of the article upon submission and before peer-review. There can be important differences between the submitted version and the official published version of record. People interested in the research are advised to contact the author for the final version of the publication, or visit the DOI to the publisher's website.

- The final author version and the galley proof are versions of the publication after peer review.

- The final published version features the final layout of the paper including the volume, issue and page numbers.

Link to publication

\footnotetext{
General rights rights.

- You may freely distribute the URL identifying the publication in the public portal. please follow below link for the End User Agreement:

www.umlib.nl/taverne-license

Take down policy

If you believe that this document breaches copyright please contact us at:

repository@maastrichtuniversity.nl

providing details and we will investigate your claim.
}

Copyright and moral rights for the publications made accessible in the public portal are retained by the authors and/or other copyright owners and it is a condition of accessing publications that users recognise and abide by the legal requirements associated with these

- Users may download and print one copy of any publication from the public portal for the purpose of private study or research.

- You may not further distribute the material or use it for any profit-making activity or commercial gain

If the publication is distributed under the terms of Article 25fa of the Dutch Copyright Act, indicated by the "Taverne" license above,

Download date: 26 Apr. 2023 
Lung cancer

\title{
Individualised isotoxic accelerated radiotherapy and chemotherapy are associated with improved long-term survival of patients with stage III NSCLC: A prospective population-based study
}

\author{
Dirk De Ruysscher ${ }^{\mathrm{a}, *}$, Angela van Baardwijk ${ }^{\mathrm{a}}$, Jessie Steevens ${ }^{\mathrm{b}}$, Anita Botterweck ${ }^{\mathrm{a}}$, Geert Bosmans ${ }^{\mathrm{a}}$, \\ Bart Reymen ${ }^{\mathrm{a}}$, Rinus Wanders ${ }^{\mathrm{a}}$, Jacques Borger ${ }^{\mathrm{a}}$, Anne-Marie C. Dingemans ${ }^{\mathrm{c}}$, Gerben Bootsma ${ }^{\mathrm{d}}$, \\ Cordula Pitz ${ }^{\mathrm{e}}$, Ragnar Lunde ${ }^{\mathrm{f}}$, Wiel Geraedts ${ }^{\mathrm{g}}$, Michel Oellers ${ }^{\mathrm{a}}$, Andre Dekker ${ }^{\mathrm{a}}$, Philippe Lambin ${ }^{\mathrm{a}}$ \\ ${ }^{a}$ Department of Radiation Oncology, Maastricht University Medical Centre; ${ }^{\mathrm{b}}$ Comprehensive Cancer Centre The Netherlands, Maastricht, The Netherlands; ${ }^{\mathrm{c}}$ Department of

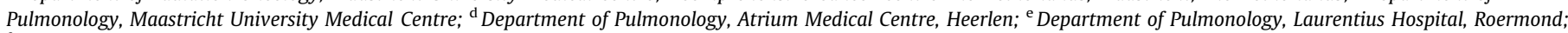 \\ ${ }_{\mathrm{f}}^{\mathrm{f}}$ Department of Pulmonology, St. Jansgasthuis, Weert; ${ }^{\mathrm{g}}$ Department of Pulmonology, Orbis Medical Centre, Sittard, The Netherlands
}

\section{A R T I C L E I N F O}

\section{Article history:}

Received 25 May 2011

Received in revised form 19 October 2011

Accepted 20 October 2011

Available online 17 November 2011

\section{Keywords:}

Non-small cell lung cancer

Radiotherapy

Chemotherapy

Stage III

Combined modality treatment

Individualised

\begin{abstract}
A B S T R A C T
Background: Individualised, isotoxic, accelerated radiotherapy (INDAR) allows the delivery of high biological radiation doses, but the long-term survival associated with this approach is unknown.

Methods: Patients with stage III NSCLC in the Netherlands Cancer Registry/Limburg from January 1, 2002 to December 31, 2008 were included.

Results: Patients (1002) with stage III NSCLC were diagnosed, of which 938 had T4 and/or N2-N3 disease. Patients treated with curative intent were staged with FDG-PET scans and a contrast-enhanced CT or an MRI of the brain. There were no shifts over time in the patient or tumour characteristics at diagnosis. The number of stage III NSCLC patients remained stable over time, but the proportion treated with palliative intent decreased from $47 \%$ in 2002 to $37 \%$ in 2008 , and the percentage treated with chemo-radiation (RT) increased from $24.6 \%$ in 2002 to $47.8 \%$ in 2008 ( $p<0.001)$. The proportion of surgical patients remained below $5 \%$. Sequential chemotherapy and conventional RT resulted in a median and a 5-year survival of 17.5 months and $8.4 \%$, respectively, whereas with sequential chemotherapy and INDAR this was 23.6 months and $31 \%$, respectively $(p<0.001)$. Concurrent chemotherapy and INDAR was associated with a median and 2-year survival that was not reached and $66.7 \%$, respectively $(p=0.004)$.

Conclusions: The proportion of patients treated with a curative intention with chemo-RT has increased markedly over time of observation. INDAR is associated with longer survival when compared to standard dose RT alone given with or without chemotherapy.
\end{abstract}

(ㄷ) 2011 Elsevier Ireland Ltd. All rights reserved. Radiotherapy and Oncology 102 (2012) 228-233
Non-small cell lung cancer (NSCLC) continues to be the leading cause of cancer deaths [1]. Stage III, that represents approximately one third of NSCLC cases, is heterogeneous, which is reflected in the diversity of the treatment. Some less advanced subgroups are treated with chemotherapy and surgery, while the majority of cases, presenting with $\mathrm{T} 4$ tumours and/ or N2 or N3 disease, receive chemotherapy and radiotherapy [2]. A randomised phase III trial that compared surgery with radiotherapy to a dose of $60 \mathrm{~Gy}$ in 30 fractions in 6 weeks after induction chemotherapy in patients with irresectable N2 disease did not find a difference in survival between both arms [3]. Another randomised phase III study investigated the role of surgery after induction concurrent

\footnotetext{
* Corresponding author. Address: Department of Radiation Oncology (MAASTRO), GROW School for Oncology and Developmental Biology, Maastricht University Medical Centre Maastricht (MUCM+), Maastricht, The Netherlands.

E-mail address: dirk.deruysscher@maastro.nl (D. De Ruysscher).
}

chemo-radiation (45 Gy) vs. concurrent chemo-radiotherapy alone (61 Gy) in NSCLC patients with resectable N2 disease, of whom 75\% had single-nodal station involvement [4]. No difference in overall survival between both arms was observed. A meta-analysis based on individual patient data showed that concurrent chemotherapy and radiotherapy resulted in improved long-term survival compared to sequential chemo-radiation, but at the expense of more, but transient, oesophageal toxicity [5]. In this meta-analysis, most patients received a radiation dose of approximately $60 \mathrm{~Gy}$ in 30 fractions in 6 weeks. At present, concurrent chemotherapy with radiotherapy to a dose of $60 \mathrm{~Gy}$ in 30 daily fractions is thus considered to be the standard treatment, as is reflected in the standard arm of the ongoing phase III study RTOG 0617 that investigates whether radiation dose-escalation would be beneficial. Indeed, indirect evidence suggests that radiation dose escalation may improve survival also in the context of chemo-radiation [6]. In case only radiotherapy is delivered, the CHART phase III study has 
shown that accelerated radiotherapy improved survival compared to standard fractionation [7]. These results could however not be confirmed in the recent CHARTWEL phase III trial, although an exploratory subgroup analysis suggested that with the addition of chemotherapy, accelerated radiotherapy may improve survival over standard fractionation [8]. On the other hand, a meta-analysis based on individual patient data did show that even without systemic therapy, very accelerated radiotherapy schedules improved significantly 5-years survival rates [9].

Because of technical and biological advances of radiotherapy for lung cancer [10], it recently became possible to individualise radiotherapy making the delivery of iso-toxic doses feasible and promising [11]. As such, biological doses of over $80 \mathrm{~Gy}$, but with toxicity levels that are comparable to $65 \mathrm{~Gy}$ could be given [11]. The same individualised approach has been investigated in concurrent chemo-radiation schedules, with promising results as well [12].

The question still remains what the impact of these advances in radiotherapy schedules is on a population basis, i.e. if we are able to demonstrate an improved survival outside of clinical trials.

We therefore investigated the survival of patients with stage III NSCLC treated with different schedules in a large, prospective population-based cancer registry.

\section{Patients and methods}

\section{Netherlands Cancer Registry/Limburg (NCR/L)}

All patients with a pathological diagnosis of NSCLC [13] in South- and Middle Limburg and with stage III (UICC 6th Edition) [14] from January 1, 2002 to December 31, 2008 were included. Data were obtained from the population-based Netherlands Cancer Registry (NCR) of the Comprehensive Cancer Centre the Netherlands. The NCR/L is a population-based cancer registry, which was established in 1984 and is a department of the Comprehensive Cancer Centre Netherlands-Location Maastricht. The NCR/L covers the region of mid- and southern Limburg, which is situated in the southeast of The Netherlands. On 1 January 2006, the region covered a total of 853,553 inhabitants. In this region, Maastro clinic is the only radiotherapy centre, in which nearly all patients needing radiotherapy are being treated. Patients that were referred to Maastro clinic from centres outside of the NCR/L were not included in this series.

Information on topography and morphology was coded according to the International Classification of Diseases for Oncology (3rd ed.) [13]. Completeness of case ascertainment of the MCR is very high; for lung cancer, this is estimated to be $>95 \%$ [15].

\section{Co-morbidity}

Co-morbidity of all lung cancer patients was scored using the Charlson co-morbidity index (CCI) [16]. Co-morbidity was defined as disease that was present at the time of diagnosis.

\section{Staging and treatment}

Only patients without a malignant pleural or cardiac effusion were offered treatment with curative intent. Patients were staged with a whole body ${ }^{18}$ F-deoxyglucose (FDG)-Positron Emission Tomography (PET) scan and a CT or MRI of the brain unless on a regular CT scan of the chest and the upper abdomen metastases were already visualised. Patients were treated according to standard regional protocols.

According to the regional guidelines, the treatment of choice for patients with stage III (T4 and/or N2-3) NSCLC was chemo-radiotherapy in patients with less than $10 \%$ of weight loss over the last 6 months and a WHO performance status of $0-2$. Patients with
T3N1M0 tumours were treated with a lobectomy and a lobespecific nodal dissection, followed by adjuvant chemotherapy from 2007. When a T4 tumour was defined on the basis of multiple nodes in the same lobe and no N2 disease was found, a lobectomy and a lobe-specific nodal dissection was done.

In practice, however, the multidisciplinary team, comprising at least a pulmonologist specialised in lung cancer, a thoracic surgeon, a radiation oncologist, a radiologist, a nuclear medicine specialist and a pathologist, was left free to choose the most appropriate treatment for an individual patient.

Sequential chemotherapy consisted or cisplatin $\left(75 \mathrm{mg} / \mathrm{m}^{2}\right)$ or carboplatin (AUC 5) on day 1 and gemcitabine $1250 \mathrm{mg} / \mathrm{m}^{2}$ on day 1 and 8 . Cycles were repeated every 21 days for a total of 3 cycles. The carboplatin dose in milligrams was based on the target AUC [5] X (glomerular filtration rate +25 ), with the glomerular filtration rate calculated according to the Cockroft-Gault formula. Standard dose-reduction rules were applied if indicated. In nonprogressive patients (RECIST criteria) [17], based on a CT scan of the chest, the primary tumour and the involved lymph nodes were treated with radiotherapy. The dose was specified according to ICRU 50 guidelines [18].

From 2002 to 2005, radiotherapy consisted of a dose of $60 \mathrm{~Gy}$ in 30 fractions in 6 weeks.

In the period from 2006 onwards, individualised iso-toxic accelerated radiotherapy (INDAR) to the primary tumour and the pretreatment involved lymph nodes on FDG-PET-CT scan was given $[11,19]$. The mean radiation dose was $64.8 \mathrm{~Gy}$ given in 36 bi-daily fractions of $1.8 \mathrm{~Gy}$ with at least $8 \mathrm{~h}$ of inter-fraction interval in an overall treatment time of 3.6 weeks was given [11]. This is a biological equivalent of a dose of $82 \mathrm{~Gy}$ in 41 daily fractions given in 8.2 weeks.

Patients who were considered to be not fit enough for chemotherapy by the multidisciplinary team were sometimes treated with high-dose radiotherapy. From 2002 to 2005, this was $60 \mathrm{~Gy}$ given in 30 daily fractions, five times per week, and from 2006 onwards, INDAR was used.

From 2006, concurrent chemo-radiation was used. After 1 or 2 cycles of carboplatin-gemcitabine, concurrent cisplatin-vinorelbine (cisplatin $50 \mathrm{mg} / \mathrm{m}^{2}$ day 2 and 9 , vinorelbine $20 \mathrm{mg} / \mathrm{m}^{2}$ day 2 and 9 , cisplatin $40 \mathrm{mg} / \mathrm{m}^{2}$ day 23 , vinorelbine $15 \mathrm{mg} / \mathrm{m}^{2}$ day 23 and 30; day 1 is the first day of radiotherapy) and radiotherapy to the primary tumour and the lymph nodes involved on FDG-PET-CT was given. In some cases, concurrently with radiotherapy, two 21-day cycles of cisplatin ( $75 \mathrm{mg} / \mathrm{m}^{2}$ day 1 ) and etoposide $\left(100 \mathrm{mg} / \mathrm{m}^{2}\right.$ day $\left.1-3\right)$ were administered. Individualised iso-toxic accelerated radiotherapy with analogous normal tissue constraints as those for sequential chemo-radiotherapy $[11,12]$ was given. In the first three weeks, 30 twice-daily fractions of $1.5 \mathrm{~Gy}$ were given, followed by once-daily fractions of $2 \mathrm{~Gy}$ [20] until a mean lung dose of $19 \mathrm{~Gy}$ was reached, with a minimum dose of $54 \mathrm{~Gy}$ and a maximum of $69 \mathrm{~Gy}$. A mean radiation dose to the tumour and the involved lymph nodes of $65 \mathrm{~Gy}$ delivered in 5.5 weeks was given. This corresponds to a biological equivalent of $72 \mathrm{~Gy}$ given in 36 daily fractions in 7.2 weeks.

For patients not treated with curative intent, the treatment was left to the discretion of the treating physician. Both best supportive care, including palliative radiotherapy, and chemotherapy, mainly consisting of carboplatin and gemcitabine were given. Targeted agents were not employed outside of clinical trials in the time periods studied in the present report.

\section{Follow-up}

Patients were seen by the pulmonologist or the radiation oncologist the first weeks after the end of treatment until the acute sideeffects resolved to grade 1 , and thereafter every three months the 
first two years, every six months from year 3 to 5 and every year after 5 years. A CT scan or an X-ray of the chest was done regularly or on indication.

\section{Statistics}

Patient characteristics were expressed as mean \pm standard deviation (SD) and their range. Differences between proportions were calculated with Chi-square tests. Survival was calculated from the date of diagnosis till death using the Kaplan-Meier method with SPSS Statistics version 17.0. Median survival rates are expressed together with their 95\% confidence intervals (CI). Survival comparison between groups was calculated with the log-rank test. Differences with a $p$-value $<0.05$ were considered significant.

The minimal follow-up time of all patients is 2 years. Survival was updated in January 2011.

\section{Results}

From January 1, 2002 to December 31, 2008, 1002 patients with stage III NSCLC were diagnosed. From this group, 64 had a T3N1 tumour. Because this group is considered to be a surgical indication, unless co-morbid conditions preclude this, these patients were omitted from the present analysis.

Patient characteristics are summarised in Table 1.

Only $27.8 \%$ of the patients did not have co-morbidities, with 26.9\% having Chronic Obstructive Pulmonary Disease (COPD), $18.3 \%$ a myocardial infarction, $16.4 \%$ hypertension, $14.3 \%$ another

Table 1

Patients characteristics of all 938 stage III NSCLC patients.

\begin{tabular}{|c|c|}
\hline Mean* & Proportion (\%) \\
\hline \multicolumn{2}{|l|}{ Gender } \\
\hline Male & 71.1 \\
\hline Female & 28.9 \\
\hline $66.7 \pm$ & \\
\hline$<50$ years & 6.4 \\
\hline $50-59$ years & 18.3 \\
\hline $60-64$ years & 14.4 \\
\hline $65-69$ years & 15.2 \\
\hline $70-74$ years & 21.7 \\
\hline$\geqslant 75$ years & 23.9 \\
\hline \multicolumn{2}{|l|}{ Histology } \\
\hline Squamous cell carcinoma & 31.9 \\
\hline Adenocarcinoma & 24.1 \\
\hline Adenosquamous carcinoma & 0.3 \\
\hline Large cell cancer & 43.3 \\
\hline Undifferentiated carcinoma & 0.3 \\
\hline \multicolumn{2}{|l|}{ Location } \\
\hline Upper lobes & 56.5 \\
\hline Lower lobes & 28.4 \\
\hline middle lobe & 3.2 \\
\hline Main bronchus & 8.4 \\
\hline Direct extension in adjacent lobe & 3.5 \\
\hline Right-sided & 59.6 \\
\hline Left lung & 40.5 \\
\hline \multicolumn{2}{|l|}{ Stage } \\
\hline IIIA & 30.8 \\
\hline IIIB & 69.2 \\
\hline \multicolumn{2}{|l|}{ T-stage } \\
\hline T0 & 0.2 \\
\hline $\mathrm{T} 1$ & 6.4 \\
\hline $\mathrm{T} 2$ & 31.2 \\
\hline T3 & 5.8 \\
\hline $\mathrm{T} 4$ & 56.3 \\
\hline \multicolumn{2}{|l|}{ N-stage } \\
\hline NO & 17.3 \\
\hline N1 & 1.5 \\
\hline N2 & 55.6 \\
\hline N3 & 25.6 \\
\hline
\end{tabular}

Mean \pm Standard deviation and range (between brackets). malignancy in their medical history, $14.3 \%$ cardiac arrhythmias, $10.3 \%$ diabetes mellitus, and $10.0 \%$ peripheral arterial disease. Two or more co-morbidities occurred in $37.5 \%$ of the patients, $17.5 \%$ had three or more co-morbidities, $6.6 \%$ four or more and 3.0\% five co-morbidities.

Two-hundred and eight patients only received best supportive care (BSC), which included any palliative radiotherapy, 203 patients were treated only with palliative chemotherapy, 179 patients with sequential chemotherapy and $60 \mathrm{~Gy} / 30$ fractions of radiotherapy, 127 patients received sequential chemotherapy and individualised isotoxic accelerated radiotherapy (INDAR), 66 concurrent chemotherapy and INDAR, 125 radiotherapy alone and 30 surgery with or without chemotherapy.

The number of cases with stage III NSCLC per year remained stable over time. In 2002, 138 new cases were diagnosed, in 2003: 133, in 2004: 134, in 2005: 136, in 2006: 128, in 2007: 131 and in 2008: $138(p=0.49)$.

During the time period from 2002 to 2008, only the N-staged distribution differed significantly. The proportion of patients with mediastinal lymph node involvement increased from $89.1 \%$ in 2002 to $96.3 \%$ in 2008 , with at the same time a shift from N2 to N3 disease from 17\% N3 in 2002 to $32 \%$ in 2008 ( $p=0.02$ ). Although FDG-PET was used in all time periods, these changes coincide in time with the introduction of the minimal invasive staging tools such as endobronchial ultrasound (EBUS) and trans-oesophageal (EUS) guided fine needle aspiration biopsy of mediastinal nodes [21].

Neither the T-stage distribution $(p=0.45)$, nor the age $(p=0.36)$, gender $(p=0.11)$, histology $(p=0.49)$, tumour location $(p=0.27)$ or co-morbidity $(p=0.18)$ changed between 2002 and 2008. The distribution of these parameters within the different treatment groups did not change significantly over time either.

The proportion of patients receiving BSC or palliative chemotherapy only decreased significantly $(p<0.001)$ over time. At the same time, the percentage of patients receiving chemotherapy and radiotherapy with curative intent increased from $24.6 \%$ in 2002 to $47.8 \%$ in 2008 ( $p<0.001)$ (Table 2$)$.

Surgery was only used in at maximum $5 \%$ of the patients (Table 2). Surgical patients were also highly selected. Seventeen of the thirty operated patients had a T4N0 tumour on the basis of multiple nodes in the same lung lobe. The stage distribution in the remaining 13 surgical patients who also received induction chemotherapy was: T1N2: 1 patient, T2N2: 7 patients, T4N2: 3 patients, T2N3: 2 patients.

The median survival of patients who only received BSC $(n=208)$ was 2.8 months (95\% CI $2.1-3.5$ ), with a 1 -year survival of $10.6 \%$ and a 2-year survival of $2.9 \%$.

When only chemotherapy ( $n=203$ ) was given, median survival was 9.2 months (95\% CI 7.8-10.6), and the 1-, 2-, and 5-year survival was $34.5 \%, 13.8 \%$ and $3.4 \%$.

Sequential chemotherapy and radiotherapy to a dose of $60 \mathrm{~Gy}$ in 30 daily fractions $(n=179)$ lead to a median survival of 17.5 months (95\% CI 15.0-20.0) and 1-, 2-, and 5-year survival rates of $63.7 \%, 31.8 \%$ and $8.4 \%$. Sequential chemotherapy and INDAR $(n=129)$ resulted in a median survival of 23.6 months $(95 \%$ CI 19.1-28.1) and 1-, 2-, and 5-year survivals of 73.2\%, 48.8\% and $31.0 \%$. The median survival of concurrent chemotherapy and INDAR ( $n=66$ ) was not reached at the time of analysis, but the 1 - and 2 -year survival was $80.3 \%$ and $66.7 \%$, with a maximal follow-up of 34 months in this group (Fig. 1).

Radiotherapy alone $(n=125)$ resulted in a median survival of 12.0 months (95\% CI 10.1-13.9), with a 1-, 2- and 5-year survival of $51.2 \%, 25.6 \%$ and $14.9 \%$.

The surgical group $(n=30)$ had a median survival of 16.6 months (95\% CI 8.0-25.3) with a 1-year survival of $60 \%, 2$-year of $36.7 \%$ and 5 -year of $25.7 \%$. 
Table 2

Evolution of the treatment over time.

\begin{tabular}{|c|c|c|c|c|c|c|c|}
\hline Year & 2002 & 2003 & 2004 & 2005 & 2006 & 2007 & 2008 \\
\hline Total number of patients & 138 & 133 & 134 & 136 & 128 & 131 & 138 \\
\hline \multicolumn{8}{|l|}{ Treatment (\% of total) } \\
\hline BSC/chemotherapy alone & 47,1 & 48,1 & 44 & 47 & 40,6 & 42,7 & 37 \\
\hline Sequential chemotherapy and conventional RT & 24,6 & 34,6 & 38 & 35,7 & 0 & 0 & 0 \\
\hline Sequential chemotherapy and INDAR & 0 & 0 & 0 & 9,6 & 47,8 & 40,5 & 10 \\
\hline Concurrent chemotherapy and INDAR & 0 & 0 & 0 & 0 & 0 & 0 & 37,8 \\
\hline RT alone & 24,6 & 15,1 & 12,7 & 7,3 & 7,7 & 13,7 & 11,5 \\
\hline Surgery & 3,7 & 2,2 & 5,3 & 0,8 & 3,9 & 3,1 & 3,7 \\
\hline Proportion of patients receiving chemo-radiotherapy & 24.6 & 34.6 & 38 & 45.3 & 47.8 & 40.5 & 47.8 \\
\hline
\end{tabular}

BSC, best supportive care; RT, radiotherapy; INDAR, individualised, isotoxic, accelerated radiot.

The differences in survival between the groups with BSC, chemotherapy alone, sequential chemotherapy and $60 \mathrm{~Gy}$ and sequential chemotherapy and INDAR are all significant $(p<0.001)$. The difference between sequential chemotherapy and INDAR and concurrent chemotherapy and INDAR is also significant $(p=0.004)$. There were no significant differences between the surgical group and sequential chemotherapy and $60 \mathrm{~Gy}$ conventional radiotherapy $(p=0.15)$ and sequential chemotherapy and INDAR $(p=0.38)$. However, the survival of concurrent chemotherapy and INDAR was better than with surgery $(p=0.005)$.

Patients were divided in 6 age groups: below 50 years, from 50 to 59 years, from 60 to 64 years, from 65 to 70 years, from 71 to 74 years and over 74 years. Over these age groups, the significant survival gain of sequential chemotherapy and INDAR over sequential chemotherapy and conventional radiotherapy and concurrent chemotherapy and INDAR and sequential chemo-INDAR remained $(p<0.001)$. However, as only four patients over 75 years received concurrent chemo-radiation, results in this age group with respect to the latter treatment should be viewed with caution.

Patients being treated in clinical trials or not did not have a significantly different survival inside of each treatment group.

\section{Discussion}

Even with the current standard treatment of choice, concurrent chemo-radiotherapy to a radiation dose of about $60 \mathrm{~Gy}$ in $30 \mathrm{frac}-$ tions, a median survival of about 24 months and a five-year survival of approximately $15 \%$ can be achieved in patients with stage III NSCLC [5,6]. Sequential chemotherapy and $60 \mathrm{~Gy}$ in 30 fractions results in a median survival of 18 months and a 5-year survival of $10 \%$ [5]. Moreover, a significant proportion of patients is believed not to be able to receive this aggressive therapy, mostly because of significant co-morbidity and frailty [10]. As an improvement in local tumour control results in increased survival [5-7], many groups have tried to increase the biological or the physical radiation dose [6-9,11,12,22-24], the rationale being a dose-response relation for NSCLC and radiotherapy [25]. A way to increase on an individual basis the radiotherapy dose is to escalate the dose up to normal tissue dose volume constraints and in an accelerated schedule, so-called individualised iso-toxic accelerated radiotherapy (INDAR) $[11,12]$. This strategy allows the safe delivery of biological doses that are comparable to more than $80 \mathrm{~Gy}$ in classical 2 Gy per day fractionation but with comparable toxicity to the standard $60-66$ Gy in $30-33$ daily fractions $[11,12,26]$. INDAR is achievable even in patients with very large tumour volumes. A more optimal therapeutic ratio is thus achieved [26].

In this study, we demonstrate that the introduction of INDAR delivered after chemotherapy increased both the median survival as well as the 5-year survival rates of patients with stage III NSCLC. Median survival increased from 17.5 months to 23.6 months and the 5 -year survival from $8.4 \%$ to $31 \%$. The concurrent administration of INDAR with chemotherapy further increased the survival.
Obviously, because this is not a randomised trial, the results may be biased in favour of the more recently treated patients. However, during the whole studied time frame from 2002 to 2008 , the standard staging did not change. All patients in all time periods were staged by means of FDG-PET scanning and received appropriate brain imaging, either with a contrast-enhanced CT scan or an MRI scan. Moreover, although the number of patients with stage III NSCLC remained stable over time, the proportion which was treated with curative intent and with chemo-radiation increased in recent years. The distribution of co-morbidities, gender, age and pathology did not change over time, thus supporting that the improved results are neither due to improved staging and hence stage migration nor to a better selection of patients. A prescription bias can nevertheless not be ruled out, for the ultimate treatment decision was made by multidisciplinary teams in different referring hospitals. On the other hand, as the NCR/L is a population-based cancer registry and covers more than $95 \%$ of all cancer cases in the region, this reduces the likelihood for case selection very much. The only time-trend observed was a shift to more N3 node involvement, possibly due to a higher use of EBUS and EUS. A change over time in e.g. supportive care cannot be ruled out and this may also have had an impact on the survival rates.

As Maastro clinic is the only radiotherapy centre in South and Middle Limburg, The Netherlands, and only very few patients are treated elsewhere, the present series is both a population based and a single-centre study.

The results of sequential chemotherapy and conventional radiotherapy and for surgery in our population-based study are in line with literature $[3-5,27,28]$. The treatment with which INDAR is compared is thus a realistic benchmark. Of interest is also that about $15 \%$ of these PET-staged patients, who were only treated with local radiotherapy, had a 5 -year survival of about $15 \%$. This underscores the need for further development of prognostic tools to identify individual patients who are likely to benefit from a further intensification of their local treatment [29-32]. It should not be forgotten that at the time period in this trial, stage III included "wet" T4 tumours with malignant pleuritis or pericarditis. These patients were therefore included in this analysis and may also explain the relatively high proportion of stage III patients being treated palliatively.

It should be acknowledged that the obtained 5-year survival rates, which are amongst the highest reported in literature, cannot be compared straightforward with other series because it cannot be excluded that the meticulous staging we used may have improved the survival as well.

Recently, there has been a wealth of publications pointing to improvements of all parts of the chain in lung cancer radiotherapy, going from target volume delineation and for the identification of prognosticators before and during treatment for tumour response and normal tissue complications using multi-factorial parameters [33-42] and the development of dose-painting trials [43]. These developments, together with the observation that intensive 


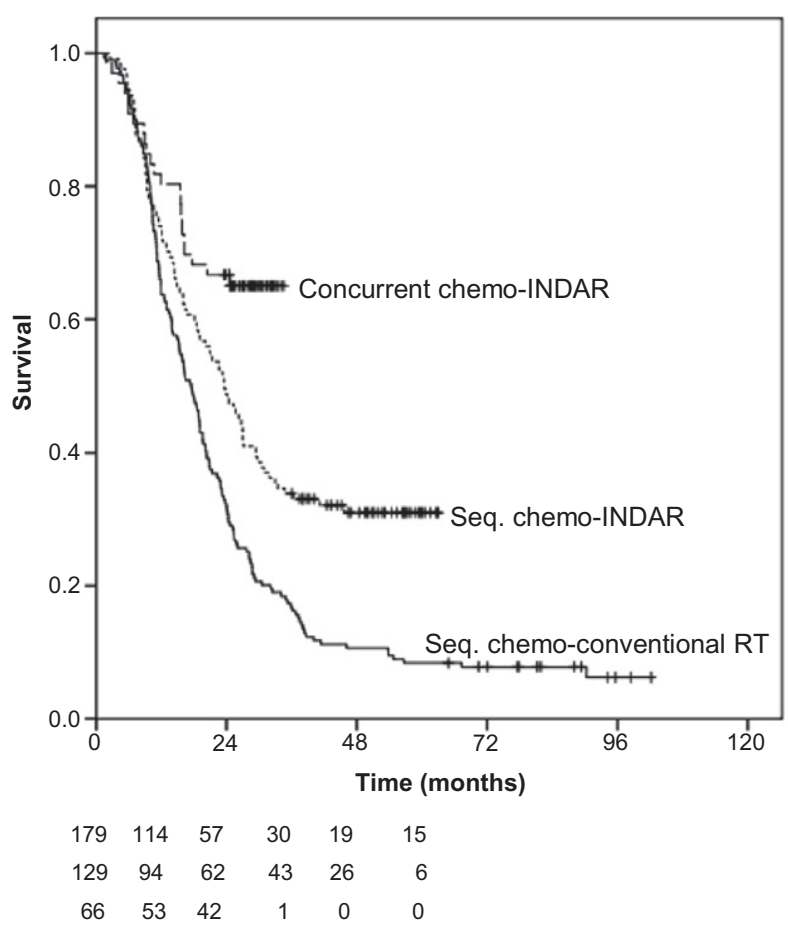

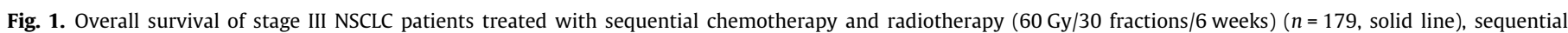

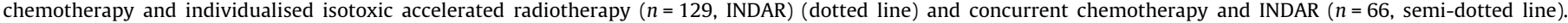
Sequential chemo-radiotherapy ( $60 \mathrm{~Gy} / 30$ fractions/6 weeks vs. sequential INDAR: $p<0.001)$; sequential INDAR vs. concurrent INDAR; $p=0.004$.

chemo-radiotherapy has no influence on the long-term quality of life of lung cancer patients [44] and may even improve dyspnoea $[11,45]$ support the use of high-dose radiotherapy in lung cancer patients further.

INDAR is obviously more costly and less convenient than oncedaily fractionation. A study with individualised, accelerated, isotoxic radiotherapy using moderate once-daily hypofractionation is therefore being tested in an ongoing trial.

In summary, the results of this prospective population-based registry show that the introduction of individualised isotoxic accelerated radiotherapy was associated with improved long-term survival of patients with stage III NSCLC.

\section{Conflict of interest statement}

None declared.

\section{References}

[1] Jemal A, Bray F, Center MM, et al. Global cancer statistics. CA Cancer J Clin 2011;61:69-90.

[2] Anderson CS, Curran WJ. Combined modality therapy for stage III non-smallcell lung cancer. Semin Radiat Oncol 2011;20:186-91.

[3] van Meerbeeck JP, Kramer GW, Van Schil PE, et al. Randomized controlled trial of resection versus radiotherapy after induction chemotherapy in stage IIIA-N2 non-small-cell lung cancer. J Natl Cancer Inst 2007;99:442-50.

[4] Albain KS, Swann RS, Rusch VW, et al. Radiotherapy plus chemotherapy with or without surgical resection for stage III non-small-cell lung cancer: a phase III randomised controlled trial. Lancet 2009;374:379-86.

[5] Aupérin A, Le Péchoux C, Rolland E, et al. Meta-analysis of concomitant versus sequential radiochemotherapy in locally advanced non-small-cell lung cancer. J Clin Oncol 2010;28:2181-90.

[6] Machtay M, Bae K, Movsas B, et al. Higher biologically effective dose of radiotherapy is associated with improved outcomes for locally advanced nonsmall cell lung carcinoma treated with chemoradiation: An Analysis of the Radiation Therapy Oncology Group. Int J Radiat Oncol Biol Phys 2012;82:423-32.

[7] Saunders M, Dische S, Barrett A, et al. Continuous, hyperfractionated, accelerated radiotherapy (CHART) versus conventional radiotherapy in nonsmall cell lung cancer: mature data from the randomised multicentre trial. CHART Steering committee. Radiother Oncol 1999;52:137-48.
[8] Baumann M, Herrmann T, Koch R, et al. Final results of the randomized phase III CHARTWEL-trial (ARO 97-1) comparing hyperfractionated-accelerated versus conventionally fractionated radiotherapy in non-small cell lung cancer (NSCLC). Radiother Oncol 2011;100:76-85.

[9] Le Pechoux C, Mauguen A, Baumann M, et alOn behalf of the MAR-LC Collaborative Group. Evaluation of modified fractionation radiotherapy effect in non metastatic lung cancer: an updated individual patients data metaanalysis on 10 randomized trials and 2685 patients. 14th World Conference on Lung Cancer, Amsterdam, July 2011. J Thorax Oncol 2011;6:432-3.

[10] De Ruysscher D, Faivre-Finn C, Nestle U, et al. European organisation for research and treatment of cancer recommendations for planning and delivery of high-dose, high-precision radiotherapy for lung cancer. J Clin Oncol 2010;28:5301-10.

[11] van Baardwijk A, Wanders S, Boersma L, et al. Mature results of an individualized radiation dose prescription study based on normal tissue constraints in stages I to III non-small-cell lung cancer. J Clin Oncol 2010;28:1380-6.

[12] van Baardwijk A, Wanders R, Reymen B, et al. First results of a phase II trial investigating individualized dose-escalation based on normal tissue constraints in concurrent chemo-radiation for locally advanced non-small cell lung cancer (NSCLC) (NCT00572325). Int J Radiat Oncol Biol Phys 2010;78:S108

[13] World Health Organization. International Classification of Diseases for Oncology (ICD-O-3), 3rd ed. Geneva; 2000.

[14] Sobin LH, Wittekind Ch, editors. International Union Against Cancer (UICC). TNM Classification of Malignant Tumours. New York: Wiley-Liss; 2002.

[15] Schouten LJ, Hoppener P, van den Brandt PA, et al. Completeness of cancer registration in Limburg, The Netherlands. Int J Epidemiol 1993;22:369-76.

[16] Charlson M, Szatrowski TP, Peterson J, et al. Validation of a combined comorbidity index. J Clin Epidemiol 1994;47:1245-51.

[17] Therasse P, Arbuck S, Eisenhauer E, et al. New guidelines to evaluate the response to treatment in solid tumors. J Natl Cancer Inst 2000;92:205-16.

[18] ICRU Report 50. Prescribing, Recording, and reporting Photon Beam Therapy International Commission on Radiation Units and Measurements. 1993.

[19] De Ruysscher D, Wanders S, van Haren E, et al. Selective mediastinal node irradiation based on FDG-PET scan data in patients with non-small-cell lung cancer: a prospective clinical study. Int $\mathrm{J}$ Radiat Oncol Biol Phys 2005;62:988-94.

[20] Pöttgen C, Eberhardt WE, Gauler T, et al. Intensified high-dose chemoradiotherapy with induction chemotherapy in patients with locally advanced non-small-cell lung cancer-safety and toxicity results within a prospective trial. Int J Radiat Oncol Biol Phys 2010;76:809-15.

[21] Annema JT, van Meerbeeck JP, Rintoul RC, et al. Mediastinoscopy vs endosonography for mediastinal nodal staging of lung cancer: a randomized trial. JAMA 2010;304:2245-52.

[22] Belderbos JS, Heemsbergen WD, De Jaeger K, et al. Final results of a Phase I/I dose escalation trial in non-small-cell lung cancer using three-dimensional conformal radiotherapy. Int J Radiat Oncol Biol Phys 2006;66:126-34. 
[23] Kong FM, Ten Haken RK, Schipper MJ, et al. High-dose radiation improved local tumor control and overall survival in patients with inoperable/unresectable non-small-cell lung cancer: long-term results of a radiation dose escalation study. Int J Radiat Oncol Biol Phys 2005;63:324-33.

[24] De Ruysscher D, Wanders R, van Haren E, et al. HI-CHART: a phase I/II study on the feasibility of high-dose continuous hyperfractionated accelerated radiotherapy in patients with inoperable non-small-cell lung cancer. Int J Radiat Oncol Biol Phys 2008;71:132-8.

[25] Partridge M, Ramos M, Sardaro A, et al. Dose escalation for non-small cell lung cancer: analysis and modelling of published literature. Radiother Oncol 2011;99:6-11.

[26] van Baardwijk A, Bosmans G, Bentzen SM, et al. Radiation dose prescription for non-small-cell lung cancer according to normal tissue dose constraints: an in silico clinical trial. Int J Radiat Oncol Biol Phys 2008;71:1103-10.

[27] Lorent N, De Leyn P, Lievens Y, et al. Long-term survival of surgically staged IIIA-N2 non-small-cell lung cancer treated with surgical combined modality approach: analysis of a 7-year prospective experience. Ann Oncol 2004; $15: 1645-53$.

[28] Garrido P, González-Larriba JL, Insa A et al. Long-term survival associated with complete resection after induction chemotherapy in stage IIIA (N2) and IIIB (T4N0-1) non small-cell lung cancer patients: the Spanish Lung Cancer Group Trial 9901. J Clin Oncol 2007;25:4736-42.

[29] Dehing-Oberije C, Aerts H, Yu S, et al. Development and Validation of a prognostic model using blood biomarker information for prediction of survival of non-small-cell lung cancer patients treated with combined chemotherapy and radiation or radiotherapy alone (NCT00181519, NCT00573040, and NCT00572325). Int J Radiat Oncol Biol Phys 2011;81:360-8.

[30] Zhu CQ, Ding K, Strumpf D, et al. Prognostic and predictive gene signature for adjuvant chemotherapy in resected non-small-cell lung cancer. J Clin Onco 2010;28:4417-24.

[31] Huang YT, Heist RS, Chirieac LR, et al. Genome-wide analysis of survival in early-stage non-small-cell lung cancer. J Clin Oncol 2009;27:2660-7.

[32] Lambin P, Petit SF, Aerts HJ, et al. The ESTRO Breur Lecture 2009. From population to voxel-based radiotherapy: exploiting intra-tumour and intraorgan heterogeneity for advanced treatment of non-small cell lung cancer Radiother Oncol 2010;96:145-52.

[33] Gaede S, Olsthoorn J, Louie AV, et al. An evaluation of an automated 4D-CT contour propagation tool to define an internal gross tumour volume for lung cancer radiotherapy. Radiother Oncol 2011;101:322-8.
[34] Siedschlag C, Boersma L, van Loon J, et al. The impact of microscopic disease on the tumor control probability in non-small-cell lung cancer. Radiother Oncol 2011;100:344-50.

[35] St-Hilaire J, Lavoie C, Dagnault A, et al. Functional avoidance of lung in plan optimization with an aperture-based inverse planning system. Radiother Oncol 2011;100:390-5.

[36] McCurdy MR, Wazni MW, Martinez J, et al. Exhaled nitric oxide predicts radiation pneumonitis in esophageal and lung cancer patients receiving thoracic radiation. Radiother Oncol 2011;101:443-8.

[37] Lopez Guerra JL, Wei Q, Yuan X, et al. Functional promoter rs2868371 variant of HSPB1 associates with radiation-induced esophageal toxicity in patients with non-small-cell lung cancer treated with radio(chemo)therapy. Radiother Oncol 2011;101:271-7.

[38] Bertelsen A, Schytte T, Bentzen SM, et al. Radiation dose response of normal lung assessed by Cone Beam CT - a potential tool for biologically adaptive radiation therapy. Radiother Oncol 2011;100:351-5.

[39] Dehing-Oberije C, De Ruysscher D, Petit S, et al. Development, external validation and clinical usefulness of a practical prediction model for radiationinduced dysphagia in lung cancer patients. Radiother Oncol 2010;97:455-61.

[40] De Ruysscher D, Houben A, Aerts HJ, et al. Increased (18)F-deoxyglucose uptake in the lung during the first weeks of radiotherapy is correlated with subsequent Radiation-Induced Lung Toxicity (RILT): a prospective pilot study. Radiother Oncol 2009;91:415-20.

[41] De Ruyck K, Sabbe N, Oberije C, et al. Development of a multicomponent prediction model for acute esophagitis in lung cancer patients receiving chemoradiotherapy. Int J Radiat Oncol Biol Phys 2011;81:537-44.

[42] Dehing-Oberije C, De Ruysscher D, van Baardwijk A, et al. The importance of patient characteristics for the prediction of radiation-induced lung toxicity. Radiother Oncol 2009;91:421-6.

[43] Aerts HJ, Lambin P, Ruysscher DD. FDG for dose painting: a rational choice. Radiother Oncol 2010;97:163-4.

[44] Pijls-Johannesma M, Houben R, Boersma L, et al. High-dose radiotherapy or concurrent chemo-radiation in lung cancer patients only induces a temporary, reversible decline in QoL. Radiother Oncol 2009;91:443-8.

[45] De Ruysscher D, Dehing C, Yu S, et al. Dyspnea evolution after high-dose radiotherapy in patients with non-small cell lung cancer. Radiother Oncol 2009;91:353-9. 